\title{
EVALUATION OF GENETIC VARIABILITY OF FRESHWATER PRAWN COLLECTED FROM MAKASSAR-SULAWESI, PANGKALANBUN- KALIMANTAN, JAMBI-SUMATRA, SUKABUMI-JAVA, AND GIMacro USING mIDNA CO-I MARKERS
}

\author{
Estu Nugroho*), Mulyasari*), Anang Hari Kristanto"), Fauzan Ali**), and Gunawan $^{* *}$
}

\begin{abstract}
The objective of this research is to evaluate the genetic variability of freshwater prawn, Macrobrachium rosenbergii. The genetic variability of freshwater prawn collected from Makassar-Sulawesi, Pangkalanbun-Kalimantan, Jambi-Sumatra, SukabumiJava, and GIMacro strain was examined using polymorphism of the mitochondria DNA (mtDNA) markers. Twelve composite haplotypes were detected following digestion of COI sequences with four endonucleases: Hae III, Rsa I, Mbo I, and Tag I. The average haplotype diversity was 0.217 . Significant genetic difference was observed among freshwater prawn populations, especially among Makassar-Sulawesi population and others. Makassar-Sulawesi strain has future prospect for genetic resources in breeding program.
\end{abstract}

KEYWORDS: genetic variability, freshwater prawn, mtDNA CO-I

\section{INTRODUCTION}

Giant freshwater prawn (Macrobrachium rosenbergii) is an indigeneous species in Indonesia. It distributes widely in Indonesian archipelago with spesific advantage for location. Giant freshwater prawn from PangkalanbunKalimantan has big head, long claw "capit" and yellow-green in collour. While its from Kuala Tungkal-Jambi has small head, short capit and gold in collour (Sabar \& Ali, 2001).

Giant freshwater prawn is an important commodity successfully cultured in Indonesia. Freshwater prawn has been developed in several areas of West Java i.e. Ciamis (Tambaksari, Parigi, Rancah, and Pasir Nagara) and Tasikmalaya. Some commercial hatcheries are found in Jogjakarta areas; the local government hatchery, and the private which controls seven hatcheries. While in East Java, freshwater prawn culture is conducted in brackish water pond.
Development of freshwater prawn culture also spread in some area of Bali Island e.g. Gianyar, Klungkung, Buleleng, and Tabanan; and also observed in Riau, South Sulawesi, and South Sumatra.

Freshwater population in Indonesia is unique and their geographical distributions are recognized as the center of origin freshwater prawn due to about 19 species are located in almost all islands of Indonesia and is still existing (Holthuis, 1980). However, this potential genetic resource has not been used yet in freshwater prawn culture. Further, despite the freshwater prawn culture has been widely developed in Indonesia, in fact some problems have been found e.g. declining of growth rate, disease, and small edible portion. To solve the problem, Research Institute for Freshwater Aquaculture (Formerly RIFF) has started a numerous program since 1996 with the main target in improvement growth rate and edible portion.

\footnotetext{
") Research Institute for Freshwater Aquaculture, Bogor, Indonesia
}

**) Indonesian Science Institute, Jakarta, Indonesia 
The selected giant freshwater prawn strain, namely by GIMacro, has been distributed to particularly farmers in Java. Various results have been obtained in different locations; therefore constructing "next" base population for selection program with addition a numerous wild strain is critically required. Assessment of their genetic background is initial step to know the variation among them. Genetic variation is important factor to evaluate individual fitness in short term and survival of population in the long term (Ferguson et al., 1995). In this research, genetic variation of giant freshwater collected from Sulawesi, Kalimantan, Sumatra, and Java has been analyzed using molecular markers.

\section{MATERIALS AND METHODS}

\section{Samples of $M$. rosenbergii}

Thirty two samples of wild giant freshwater prawn were collected from Makassar-Sulawesi, Pangkalanbun-Kalimantan, Sukabumi-Java, and hatchery stock of Jambi-Sumatra and GIMacro.

\section{Whole DNA extraction and amplification of mtDNA CO-I region}

Whole DNA of freshwater prawn was extracted from pleopod using a standard phenolchloroform procedure as follow: $5-10 \mathrm{mg}$ of pleopod placed into $1.5 \mathrm{~mL}$ tube containing $500 \mu \mathrm{L}$ DNA lyses solution + $120 \mu \mathrm{L} 0.5 \mathrm{M}$ EDTA $\mathrm{pH}$ 8.0. Then followed by addition of $10 \mu \mathrm{g} / \mathrm{mL}$ Proteinase $\mathrm{K}$ and incubated at $37^{\circ} \mathrm{C}$ for 12 hours. After placed into a room temperature, $500 \mu \mathrm{L}$ of phenol chloroform was added, and kept in ice for 5 minutes. Centrifuge at 10,000 rpm for 10 minutes, a supernatant was taken and placed into a new $1.5 \mathrm{~mL}$ tube, following with addition of $10 \mu \mathrm{L}$ ammonium acetate and $500 \mu \mathrm{L}$ ethanol, and then gently vortex. The pellet was suspended using centrifuge at $10,000 \mathrm{rpm}$ for 10 minutes and dried in room temperature, followed by re-suspended with 50-100 $\mu \mathrm{L}$ Tris-EDTA (TE) buffer and kept into $4^{\circ} \mathrm{C}$ before used.

Primer used to amplify mitochondrial CO-I regions was LCO-1490 (GGT CAA CAA ATC ATA AAG ATA TTG G) and HCO-2198 (TAA ACT TCA GGG TGA CCA AAA AAT CA). Amplifications of CO-I regions were conducted using Polymerize Chain Reaction (PCR) with a reaction as follows: $10 \mu \mathrm{g}$ of whole DNA, $10 \mathrm{pmol}$ of each primer and "pure taq DNA ready to go" (Promega), with total volume is $25 \mu \mathrm{L}$. PCR cycles are con- sisted of a cycle for denaturation at temperature $95^{\circ} \mathrm{C}$ for 2 minutes. 35 cycles for annealing consisted of $95^{\circ} \mathrm{C}$ for 1 minutes, $45^{\circ} \mathrm{C}$ for 1 minute and $72^{\circ} \mathrm{C}$ for 2.5 minutes, and followed with an extension cycle at $72^{\circ} \mathrm{C}$ for 10 minutes. mtDNA CO-I sequences was restricted by 7 endonucleases (Hae III, Rsa I, Mbol, Taq I, Alu I, Sac II, and Hin 6 I), and then separated using electrophoresis on 2\%-3\% agarose gel in TrisBoric-EDTA (TBE) buffer, and observed under illuminator (UV).

\section{Data Analysis}

Evaluation of DNA variation among giant freshwater prawn populations was conducted using haplotype in each restriction endonuclease that compiled as composite haplotype, and analyzed with Analyze Molecular Variance (AMOVA) and Fst value that constructed in TFPGA (Tools for Population Genetic Analysis) program. Haplotype diversity and genetic diversity were calculated based on Nei \& Tajima (1981) method to evaluate genetic variation level.

\section{RESULTS AND DISCUSSION}

MtDNA CO-I Sequence of giant freshwater prawn with size $700-1,500$ bp was amplified. Four of seven endoucleases had restriction site, i.e. Hae III, Rsal, Mbol, and Taq I. Polymorphism pattern was found using Hae III and Rsa I, while Mbol and Taq I resulted monomorphism pattern (Table 1). Six restriction patterns were obtained by Hae III, while Rsa I showed three restriction patterns. An example of restriction pattern is shown in Figure 1. The length of mtDNA CO-I sequence of giant freshwater prawn was similar to D-loop sequence that observed in other fish such as tilapia, kingfish, yellow tail, and red sea bream (Nugroho, 2001).

Haplotype variation level is influenced by location stock of giant freshwater prawn. Generally, 12 composite haplotypes were identified based on four endonucleases at mtDNA CO-I sequences. Two to five composite haplotypes were observed among collections. Giant freshwater shrimp collected from Makassar-Sulawesi showed two composite haplotypes only, while it was originated from Sukabumi-Java and GIMacro obtained 5 composite haplotypes. Haplotype diversity was varied between 0.111 (Makassar-Sulawesi) and 0.280 (Sukabumi-Java, Table 2).

Genetic variation level indicated by number of haplotype and haplotype diversity in 
Table 1. Type of enzyme and restriction site of mtDNA CO-I of giant freshwater prawn

\begin{tabular}{lcc}
\hline $\begin{array}{c}\text { Enzyme } \\
\text { type }\end{array}$ & $\begin{array}{c}\text { Restriction } \\
\text { site }\end{array}$ & $\begin{array}{c}\text { Rest riction } \\
\text { type }\end{array}$ \\
\hline Hae III & + & Polymorphic \\
Rsa I & + & Polymorphic \\
Mbo I & + & Monomorphic \\
Taq I & + & Monomorphic \\
Alu I & - & - \\
Sac II & - & - \\
Hin6 I & - & - \\
\hline
\end{tabular}

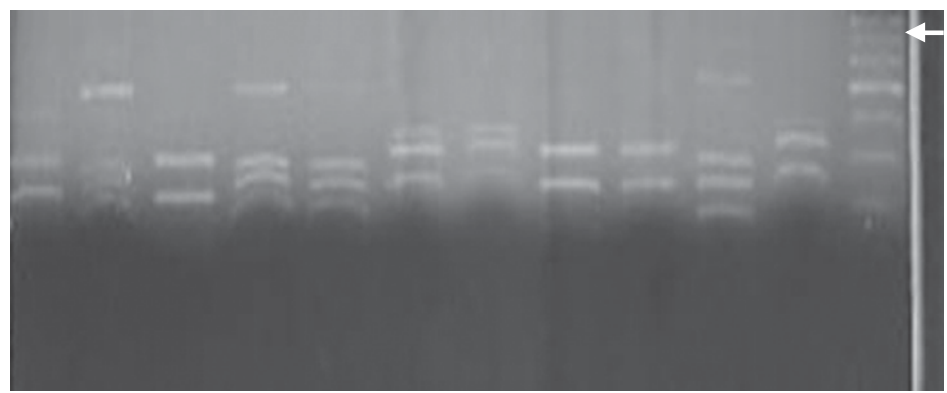

Figure 1. Restriction pattern of mtDNA CO-I region restricted by enzyme Hae III

Table 2. Composite haplotype frequency of mtDNA CO1 of freshwater prawn generated by 4 endonucleases, Hae III, Rsa I, Mbol, and Taq I

\begin{tabular}{|c|c|c|c|c|c|c|}
\hline \multirow[b]{2}{*}{ No. } & \multirow{2}{*}{$\begin{array}{l}\text { Type of } \\
\text { composite } \\
\text { haplotype }\end{array}$} & \multicolumn{5}{|c|}{ Population } \\
\hline & & $\begin{array}{c}\text { Sukabumi- } \\
\text { Java }\end{array}$ & GIMacro & $\begin{array}{l}\text { Pangkalanbun- } \\
\text { Kalimantan }\end{array}$ & $\begin{array}{l}\text { Jambi- } \\
\text { Sumatra }\end{array}$ & $\begin{array}{l}\text { Makassar- } \\
\text { Sulawesi }\end{array}$ \\
\hline 1 & BAAA & 0.200 & 0.400 & - & - & - \\
\hline 2 & CAAA & 0.200 & - & - & - & - \\
\hline 3 & ABAA & 0.200 & - & 0.333 & 0.400 & - \\
\hline 4 & BBAA & 0.200 & - & - & - & - \\
\hline 5 & AAAA & 0.200 & 0.200 & 0.167 & 0.400 & - \\
\hline 6 & BCAA & - & 0.200 & - & - & - \\
\hline 7 & CCAA & - & 0.200 & - & - & - \\
\hline 8 & ACAA & - & & 0.167 & - & - \\
\hline 9 & DBAA & - & - & 0.333 & - & - \\
\hline 10 & EBAA & - & - & - & 0.200 & - \\
\hline 11 & FBAA & - & - & - & - & 0.667 \\
\hline 12 & FAAA & - & - & - & - & 0.333 \\
\hline \multicolumn{2}{|c|}{ N-Sampel } & 5 & 5 & 6 & 5 & 6 \\
\hline \multicolumn{2}{|c|}{ N-Haplotype } & 5 & 4 & 4 & 3 & 2 \\
\hline \multicolumn{2}{|c|}{ Haplotype Diversity } & 0.280 & 0.260 & 0.236 & 0.20 & 0.111 \\
\hline
\end{tabular}


giant freshwater prawn was different to their observed in marine fish with haplotype number and diversity was $6-17$ and $0.6--0.9$ respectively (Nugroho, 2001). However, it was relatively similar to other freshwater fish, such as tilapia (Nugroho et al., 2002). Relatively low genetic variation of giant freshwater prawn was possible caused by relatively limited capability to migrate in freshwater fish compared to marine fish. Low genetic variability of giant freshwater prawn indicates that there was natural selection or genetic drift in these populations.

Further, some collections had similar major haplotype, between Sukabumi-Java and GIMacro (haplotype \#1); Sukabumi-Java, Pangkalanbun-Kalimantan, and Jambi-Sumatra (\#3); GIMacro, Sukabumi-Java, Jambi-Sumatra, and Pangkalanbun-Kalimantan (\#5); while giant freshwater prawn originated from MakassarSulawesi had specific major haplotype (\#11 and \#12). Similarity major haplotype among Sukabumi-Java and GIMacro, Jambi-Sumatra and GIMacro were caused by the same DNA sources of the giant freshwater prawn. One of them was Sukabumi-Java population consisted of disseminated GIMacro population constructed by three population of giant freshwater prawn was originated from Citanduy and Citarum (West Java), and Musi (Sumatra). Therefore there was possibility of crossing over among them including the local population. Giant freshwater prawn from PangkalanbunKalimantan had similar composite haplotype to Sukabumi-Java, Jambi-Sumatra and GIMacro, however Kalimantan collection still has specific haplotype that only found in this population (\#8 and \#9). This indicated that there was ecological barrier in the migration of this species.
Significant genetic difference was observed among giant freshwater population $(\mathrm{P}<$ 0.05) calculated using AMOVA (Analysis Molecular Variance). Fst pair wise comparison test showed that the difference was observed between giant freshwater prawns from MakassarSulawesi and those of all giant freshwater collections. Significant difference was also found between giant freshwater prawn from Pangkalanbun-Kalimantan and GIMacro (Table $3)$.

The above difference was caused by giant freshwater prawn from Makassar-Sulawesi had different major composite haplotype compared to other populations. This may indicate there was possibility that population structure of Makassar-Sulawesi populations may consist of different sub-species due to ecological barrier. de Bruyn et al. (2004), found biographical barrier in giant freshwater prawn population originated from Tanah Genting Kra. Flora and Fauna differentiation come from East and Western parts of Wallace is a phenomena that may influence to construct different population structure of Makassar-Sulawesi (East Wallace) and others (West Wallace).

Genetic distance (Nei \& Tajima, 1981) based on restriction sites from four endonucleases is listed in Table 4. The average genetic distance among population was estimated 0.1690 . The longest genetic distance was observed between Makassar-Sulawesi and GIMacro populations, while the shortest one was observed between Sukabumi-Java and GIMacro populations.

Constructed dendrogram based on the genetic distance showed three clusters were found among the tested giant freshwater populations. First group consisted of giant freshwa-

Table 3. Pairwise comparison of Fst

\begin{tabular}{lccccc}
\hline \multicolumn{1}{c}{ Population } & $\begin{array}{c}\text { Sukabumi- } \\
\text { Java }\end{array}$ & GIMacro & $\begin{array}{c}\text { Banjarmasin- } \\
\text { Kalimantan }\end{array}$ & $\begin{array}{c}\text { Jambi- } \\
\text { Sumatra }\end{array}$ & $\begin{array}{c}\text { Makassar- } \\
\text { Sulawesi }\end{array}$ \\
\hline Sukabumi-Java & - & & & & \\
GIMacro & 0.5280 & - & & & \\
$\begin{array}{l}\text { Pangkalanbun- } \\
\text { Kalimantan }\end{array}$ & 0.2376 & $0.0272^{*}$ & - & & \\
Jambi-Sumatra & 0.6480 & 0.0787 & 0.8161 & - & - \\
Makassar-Sulawesi & $0.0112^{*}$ & $0.0013^{* *}$ & $0.0093^{* *}$ & $0.0214^{*}$ & - \\
\hline
\end{tabular}

**) significant at level, $\mathrm{P}<0.01$ 
Table 4. Genetic distance among giant freshwater prawn collections

\begin{tabular}{lccccc}
\hline \multicolumn{1}{c}{ Population } & $\begin{array}{c}\text { Sukabumi- } \\
\text { Java }\end{array}$ & GIMacro & $\begin{array}{c}\text { Banjarmasin- } \\
\text { Kalimantan }\end{array}$ & $\begin{array}{c}\text { Jambi- } \\
\text { Sumatra }\end{array}$ & $\begin{array}{c}\text { Makassar- } \\
\text { Sulawesi }\end{array}$ \\
\hline Sukabumi-Java & - & & & & \\
GIMacro & 0.0289 & - & & & \\
$\begin{array}{l}\text { Pangkalanbun- } \\
\text { Kalimantan }\end{array}$ & 0.0828 & 0.2340 & - & & \\
Jambi-Sumatra & 0.0447 & 0.2147 & 0.0131 & - & - \\
Makassar-Sulawesi & 0.2325 & 0.3628 & 0.2565 & 0.2655 & - \\
\hline
\end{tabular}

ter prawn from Sukabumi-Java and GIMacro. Pangkalanbun-Kalimantan and Jambi-Sumatra populations were in second group. While giant freshwater prawn from Makassar-Sulawesi was uniquely separated from the other group (Figure 2). Relationship between GIMacro and Sukabumi-Java may indicate gene flow happened among those populations. GIMacro was disseminated to the farmers in Sukabumi-Java in 2001. While relationship between JambiSumatra and Pangkalanbun-Kalimantan may show correlation of biological variability and earth history (de Bruyn et al., 2004).

As phenotypic, Makassar-Sulawesi giant freshwater prawn had relatively bigger size as the others. It was recognized that the average body weight of this population was about 83 g. Combining with their genetic variability level based on the composite haplotype, this population was possible to be used as an inbreed line. Hybridization with other populations is an alternative breeding program in to produce high quality seed of giant freshwater prawn in Indonesia.

\section{CONCLUSIONS}

Significant genetic difference among giant freshwater prawn from Makassar-Sulawesi and the other populations was observed. The average genetic variability based on aomposite haplotype is 0.217 , with average genetic distance was 0.169 . Giant freshwater prawn from Makassar-Sulawesi is potentially used as an inbreed line in the next breeding program of giant freshwater prawn in Indonesia.

\section{ACKNOWLEDGEMENT}

This research is a partial of activity of Genetic Improvement of Macrobrachium rosenbergii in Indonesia included in Project Promotion of Sustainable Aquaculture in the ASEAN Region, funded by SEAFDEC.

\section{REFERENCES}

de Bruyn, M., E. Nugroho, Md. Mokarrom Hossain, J.C. Wilson, and P. Mather. 2004. Philogeographic Evidence for The Existence of An Ancient Biogeographic Barrier:

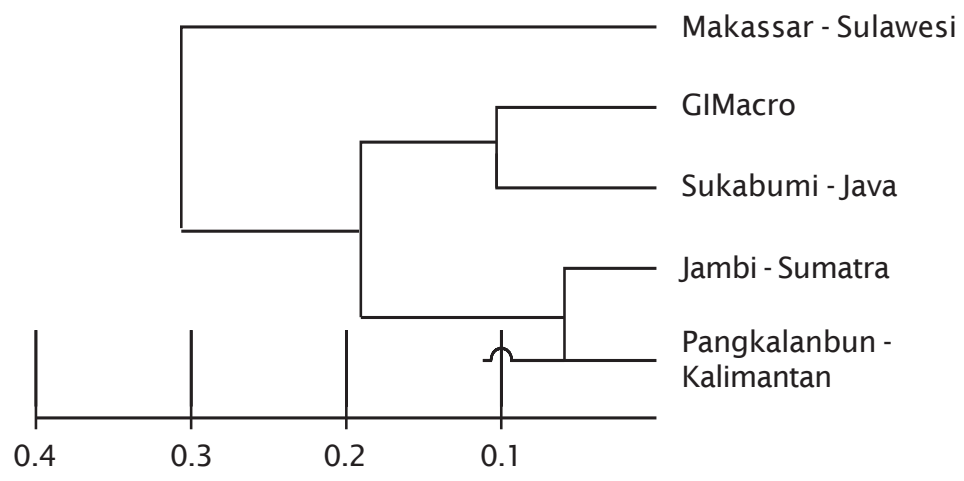

Figure 2. UPGMA dendrogram of several freshwater prawn collections 
The Isthmus of Kra Seaway. Heredity No: 1-9/2004. Nature Publishing Group.

Ferguson, A.J., A.J. Taggart, P.A. Prodohl, O. McMeel, C. Thompson, C. Stone, P. McGinnity, and R.A. Hynes. 1995. The application of molecular markers to study and conservation of fish populations, with special reference to Salmo. Journal of Fish Biology. 47: 103-126.

Holthuis, L.B. 1980. The Palemonidae, the Decapoda collected by the Sibolga and Snelius Expedition with Remark on Species I, Part X. E.J. Brill, Leiden. 114 pp.
Nei, M. and F. Tajima. 1981. DNA polymorphism detectable by restriction endonucleases. Genetics. 97: 145-163.

Nugroho, E. 2001. Population genetic studies on the aquaculture fish in genus Seriola for their risk management. PhD Thesis. Tohoku University. 123 pp.

Nugroho, E., A. Widiyati, Imron, dan T. Kadarini. 2002. Keragaan Genetik Ikan Nila GIFT Berdasarkan Polimorfisme Mitokondria DNA D-Loop. J. Pen. Perik. Indonesia. Edisi Akuakultur. 8(3): 1--6 